\title{
Internet Connection and Learning Device Availability of College Students: Basis for Institutionalizing Flexible Learning in the New Normal
}

\author{
1 John Mark R. Asio* \\ 1 Ediric D. Gadia \\ 2Erlinda C. Abarintos \\ ${ }^{3}$ Darwin P. Paguio \\ ${ }^{4}$ Melner Balce \\ ${ }^{1}$ Research Development and Community Extension Services, Gordon College, Olongapo City, Philippines \\ ${ }^{2}$ Administration and Finance Office, Gordon College, Olongapo City, Philippines \\ ${ }^{3}$ Academic Affairs Office, Gordon College, Olongapo City, Philippines \\ ${ }^{4}$ College of Computer Studies, Gordon College, Olongapo City, Philippines
}

\begin{tabular}{|c|c|c|}
\hline Received: 30.04 .2021 & - $\quad$ Accepted: 28.06.2021 & Published: 30.06 .2021 \\
\hline
\end{tabular}

\begin{abstract}
Due to the effect of the current pandemic that the world is experiencing, the educational system swiftly remedied the problem of student learning. This study assessed the students' internet connection capability and the availability of learning devices at their homes. The researchers used a descriptive cross-sectional research design with the online survey as the primary tool for data gathering. Using a convenience sampling technique, this study garnered 2,894 responses from students at a local higher education institution in Central Luzon, Philippines. The study used a modified questionnaire and subjected the gathered data to simple statistical analysis. Based on the results of the survey, $70 \%$ of the students have internet access at home. On the other hand, smartphone tops the list of the learning devices available for students' learning. To conclude, the institution can therefore implement a flexible learning plan for the students, especially this time of the pandemic period. In addition, the researchers also suggested some important recommendations in the learning system of the institution.
\end{abstract}

Keywords: Internet connection, learning devices, college students, flexible learning, new normal

\section{Introduction}

The advent of the current COVID-19 pandemic that paralyzed most human activities provided vast and unimaginable challenges for humankind. Although we are already in the technological era with the context of the Fourth Industrial Revolution (FIRe) (Akbar et al., 2018), this minute organism provided a devastating effect to all. Everyone suffered, world leaders are trying their best to contain the situation, the world's brightest mind, and the most high-tech laboratory race against time to put a stop to this ravaging curse of the $21^{\text {st }}$ century.

On the other side of the coin, since everyone is affected, even the educational system was temporarily put to a halt due to lockdown. This made face-to-face learning impossible which

\footnotetext{
* Corresponding Author: John Mark R. Asio, asio.johnmark@gordoncollege.edu.ph
} 
hampered the educational pursuit of students. All over the world, millions of students are affected and some already gave up their status of being a student. And one of the biggest challenges to address the problem regarding learning is the availability of technological gadgets and internet connectivity. There were pieces of literature that supported the argument of this study and saw the needs and challenges of internet connections among students (Aboagye et al., 2021; Chase et al., 2018; Chung et al., 2020a; Lorenzo, 2017). However, there are some also that have a different perspective when it comes to internet connectivity. An inefficient internet facility in a university is not an issue for the use of the internet in the university (Apuke \& Iyendo, 2018). Another study also spoke of the importance of enhanced internet connectivity for e-learning especially in rural areas (Ahmed et al., 2017). Based on another perspective, a majority of the respondents in a related study showed readiness for online learning (Muthuprasad et al., 2021). In another particular article by Hossain and Rahman (2017), they stipulated that students from their studies need to enhance their internet usage and further suggested that the university should provide internet facilities and an environment for students. In a related article, Tarimo and Kavishe (2017) found that $82 \%$ of students in their study use the internet for academic purposes. However, in terms of attitude towards the use of online learning management systems, a study showed negative results (Serhan, 2020). With these ideas and information, internet connection is both an issue and challenge not only for the students but also for teachers and the institution.

Another related matter in this study is the availability of learning tools or devices that is equally important. Although we are in an era where technological instruments and apparatuses are within reach, there are still some who do not have one. For example, in a particular country in South Asia, a study showed that respondents have at home and in the university, computers and internet facilities (Siddiquah and Salim, 2017). In another study, students possessed various types and brands of mobile phones especially smartphones (Essel et al., 2018). This is possible because the market of mobile phones became in demand and the prices are very competitive for consumers. Some studies showed the dependency of students on smartphones for online learning and internet access (Apuke \& Ivendo, 2018; Muthuprasad et al., 2021). But Gezgin (2017) indicated no significant difference in the duration of smartphone ownership and on the occurrence of nomophobia to university students. However, another study stated that mobile learning devices have a positive effect on students' perceived efficiency of working (Chase et al., 2018). But the most pressing issue here is the unwillingness of students towards the blended-online learning approach (Baloran, 2020).

For the local context, in the Philippines, several studies showed some contrasting sentiments with regards to internet connectivity and the use of gadgets or devices for online learning. In a study by Fabito et al., (2020) the group revealed that one of the three barriers and challenges that students encountered in online learning was a good internet connection. Another related concept from Casillano (2019) indicated that only a minimum of the students has internet access thus impeding them to access the e-learning platform. In another study, poor students do not own laptops and desktop computers and have limited internet connections (Cleofas \& Rocha, 2021). However, in the findings of Jin and Sabio (2018), the use of mobile devices has the potential to be used and adapted for learning. Another study showed that the greater number of device types owned by a student, the greater the level of learning readiness (Estira, 2020). In addition, from another state university in the country, a study revealed the students' readiness for online classes however, the burden from computer and internet rentals in cafes exists (Yra et al., 2020).

In this regard, the objective of this study is to assess the internet connection capability and learning devices availability of students for the possibility of an online or a flexible type of learning. The result of the study will provide the school administration a glimpse of how students and faculty will 
adjust their teaching-learning processes. At the same time, the result will also become a basis for institutionalizing a flexible learning approach for the time to come.

\section{Methodology}

\subsection{Research Design}

This study used a cross-sectional descriptive research design with the online survey as the primary instrument for data gathering. A descriptive research's goal is to "describe" a certain phenomenon or event and its characteristics from a certain sample of a population (Nassaji, 2015). A descriptive design provides a profile of relevant concepts of a phenomenon from an individual, organization, or industry perspective (Sileyew, 2019). Since researchers intend to analyze a certain phenomenon, then the descriptive research design is appropriate for this study.

\subsection{Respondents of the Study}

The respondents of this study are the students who enrolled last second semester of the academic year 2019-2020. Using the convenience sampling technique, all of the students were considered to be part of the survey. The convenience sampling technique selects participants due to their availability, readiness, and easiness (Taherdoost, 2016). The key advantages of such a sampling technique include speed, cheapness, and no sampling frame (Baltes \& Ralph, 2021). The researchers, therefore, agreed to use such a technique since it is applicable for the study. However, due to some valid reasons which cannot be mentioned, not all of the students were able to join and answer the online survey. A total of 2,674 participated and took the online survey for the duration of two months.

\subsection{Research Instrument}

For the instrument of the study, the proponents adapted and modified a survey questionnaire from a previous study by Gulatee and Combes (2018) which also aimed the same as the current study. The survey questionnaire has three parts. The first part includes the basic demographic profiles of the students. The second part assessed the internet connectivity and access of the students. The last section assessed the availability of the device of students for learning. The instrument also underwent a validity test and pilot-testing before the actual dissemination of the online survey.

\subsection{Statistical Analysis}

After gathering the data, the researchers tallied and tabulated the information gathered from the survey. With the use of Microsoft Excel Sheet, the researchers computed and analyzed the data. This study used frequency and percentage for the statistical analysis of the gathered data.

\section{Results}

The following tables show the initial results of the survey done by the institution to its students in preparation for the "new normal" of delivery of learning. In this regard, the result of this initial survey will help the institution prepare for the upcoming semester especially the faculty and staff regarding the teaching modality and other pertinent learning management system that may be deemed essential for the outcome of this study.

Table 1. Survey Results from the College of Computer Studies

\begin{tabular}{lccc}
\hline Items & Responses & Frequency & Percentage \\
\hline Will enroll next semester & YES & 414 & 92 \\
\hline
\end{tabular}




\begin{tabular}{llcc}
\hline & NO & 37 & 8 \\
\hline Province & Province 1 & 43 & 9 \\
& Province 2 & 407 & 90 \\
& Others & 1 & 1 \\
\hline Internet access at home & NO & 134 & 30 \\
& YES & 317 & 70 \\
\hline \multirow{2}{*}{ Wifi Access at home } & NO & 226 & 50 \\
& YES & 225 & 50 \\
\hline Pocket Wifi & NO & 418 & 93 \\
& YES & 33 & 7 \\
\hline Mobile data & NO & 199 & 44 \\
& YES & 252 & 56 \\
\hline Free Mobile data & NO & 237 & 53 \\
& YES & 214 & 47 \\
\hline No internet access & NO & 445 & 99 \\
& YES & 6 & 1 \\
\hline Smartphones & NO & 26 & 6 \\
& YES & 425 & 94 \\
\hline Tablet & NO & 447 & 99 \\
& YES & 4 & 1 \\
\hline Laptop & NO & 346 & 77 \\
& YES & 105 & 23 \\
\hline Personal Computer & NO & 431 & 96 \\
& YES & 20 & 4 \\
\hline Total & & 451 & 100 \\
\hline
\end{tabular}

* Province 1-Bataan

* Province 2 - Zambales

Table 1 shows the result of the survey for the College of Computer Studies (CCS). It can be deduced that the majority of the students will enroll for the first semester. This is represented by 414 or 92 percent of the students out of 451 who joined the survey. On the other hand, the majority of the students come from the province of Zambales accounting for 90 percent (407) of the total, followed by the province of Bataan with $43(9 \%)$. For internet access at home, there are more students (317 or $70 \%$ ) who can access the internet compared to those who do not have access (134 or 30\%). In terms of WiFi access at home, there was a split in the number of those students who have and do not have. It is also interesting to note that a majority of the students do not possess pocket WiFi (418 or 93\%) and only a few of them have it. While in terms of using mobile data from different networks, there are more who can access it with 252 or $56 \%$. The same is observed for those students who benefit from free mobile data with more than half of them ( 237 or $53 \%$ ) using it. Furthermore, almost all of the students (445 or 99\%) have access to the internet in any form. For the gadgets, the majority of the students ( 425 or $94 \%$ ) have smartphones, however, tablets, laptops, and personal computers garnered negative responses and only a portion of the students have them.

Table 2. Survey Results from the College of Allied Health Studies

\begin{tabular}{llcc}
\hline Items & Responses & Frequency & Percentage \\
\hline Will enroll next semester & YES & 309 & 90 \\
& NO & 36 & 10 \\
\hline Province & Province 1 & 24 & 7 \\
& Province 2 & 304 & 88 \\
& Others & 17 & 5 \\
\hline Internet access at home & NO & 87 & 25 \\
& YES & 258 & 75 \\
\hline
\end{tabular}


60 J.M.R. Asio et al.: Internet Connection and Learning Device Availability of College Students: Basis for Institutionalizing Flexible Learning in the New Normal

\begin{tabular}{llcc}
\hline \hline Wifi Access at home & NO & 158 & 46 \\
& YES & 187 & 54 \\
\hline Pocket Wifi & NO & 321 & 93 \\
& YES & 24 & 7 \\
\hline Mobile data & NO & 136 & 39 \\
& YES & 209 & 61 \\
\hline Free Mobile data & NO & 221 & 64 \\
& YES & 124 & 36 \\
\hline No internet access & NO & 340 & 99 \\
& YES & 5 & 1 \\
\hline Smartphones & NO & 12 & 3 \\
& YES & 333 & 97 \\
\hline Tablet & NO & 335 & 97 \\
& YES & 10 & 3 \\
\hline Laptop & NO & 288 & 83 \\
& YES & 57 & 17 \\
\hline Personal Computer & NO & 334 & 97 \\
& YES & 11 & 3 \\
\hline Total & & 345 & 100 \\
& & & \\
\hline
\end{tabular}

* Province 1-Bataan

* Province 2 - Zambales

Table 2 shows the result of the survey for the College of Allied Health Studies. As we can see, there is a majority of the respondents who will come back for the First Semester with $90 \%$ or 309 students. The majority of these students will come from the province of Zambales which accounts for 304 students (or $88 \%$ ) and from the province of Bataan with 24 or $7 \%$ and the rest (17 or 5\%) from the part of the region. In terms of internet access at home, at least three-fourths (75\% or 258 students) of the surveyed students have access. In terms of Wifi access at home, more than half of $54 \%$ of the students responded yes and the remaining was no. For the students who have pocket Wifi, the majority (93\% or 321) of the students do not have one. In terms of mobile data availability, more than 60 percent of the students use mobile data for internet surfing. On the other hand, those students who avail free mobile data were more than 60 percent of the total respondents. But a majority of the students have internet access at all (99\%). For the gadgets that can be used for learning, the majority of the students possess smartphones (97\% or 333). However, only a few of the students have a tablet (3\%), laptop (17\%), and personal computer (3\%).

Table 3. Survey Results from the College of Hospitality and Tourism Management

\begin{tabular}{llcc}
\hline Items & Responses & Frequency & Percentage \\
\hline \multirow{2}{*}{ Will enroll next semester } & YES & 294 & 88 \\
& NO & 39 & 12 \\
\hline Province & Province 1 & 26 & 8 \\
& Province 2 & 304 & 91 \\
& Others & 3 & 1 \\
\hline \multirow{2}{*}{ Internet access at home } & NO & 106 & 32 \\
& YES & 227 & 68 \\
\hline \multirow{2}{*}{ Wifi Access at home } & NO & 184 & 55 \\
& YES & 149 & 45 \\
\hline Pocket Wifi & NO & 314 & 94 \\
& YES & 19 & 6 \\
\hline Mobile data & NO & 146 & 44 \\
& YES & 187 & 56 \\
\hline
\end{tabular}




\begin{tabular}{llcc}
\hline Free Mobile data & NO & 196 & 59 \\
& YES & 137 & 41 \\
\hline No internet access & NO & 328 & 98 \\
& YES & 5 & 2 \\
\hline Smartphones & NO & 9 & 3 \\
& YES & 324 & 97 \\
\hline Tablet & NO & 324 & 97 \\
& YES & 9 & 3 \\
\hline Laptop & NO & 298 & 89 \\
& YES & 35 & 11 \\
\hline Personal Computer & NO & 324 & 97 \\
& YES & 9 & 3 \\
\hline Total & & 333 & 100 \\
\hline
\end{tabular}

* Province 1-Bataan

* Province 2 - Zambales

Table 3 shows the frequency and percentage distribution of the survey done to the College of Hospitality and Tourism Management. Almost 90 percent of the students for the CHTM will enroll this first semester. And most of these enrollees (91\%) will come from the province of Zambales, followed by the province of Bataan. There is 68 percent of the students who have internet access at home. On the other hand, more than 50 percent of the students have Wifi access at home. Only a few of the students $(6 \%)$ have pocket Wifi on the other hand. In terms of Mobile data utilization, more than 50 percent of the students use mobile data for internet usage. The same was observed that almost 60 percent of the students use free mobile data for internet purposes. It is interesting to note that a majority of the students have access to the internet as shown by 98 percent of the responses. In terms of gadgets, the majority of the students have smartphones (97\%) compared to tablets (3) laptops $(11 \%)$ and personal computers $(3 \%)$.

Table 4. Survey Results from the College of Business and Accountancy

\begin{tabular}{llcc}
\hline Items & Responses & Frequency & Percentage \\
\hline Will enroll next semester & YES & 811 & 89 \\
& NO & 102 & 11 \\
\hline Province & Province 1 & 86 & 9 \\
& Province 2 & 823 & 90 \\
& Others & 4 & 1 \\
\hline Internet access at home & NO & 324 & 35 \\
& YES & 589 & 65 \\
\hline Wifi Access at home & NO & 568 & 62 \\
& YES & 345 & 38 \\
\hline Pocket Wifi & NO & 862 & 94 \\
& YES & 51 & 6 \\
\hline Mobile data & NO & 386 & 42 \\
& YES & 527 & 58 \\
\hline Free Mobile data & NO & 499 & 55 \\
& YES & 414 & 45 \\
\hline No internet access & NO & 888 & 97 \\
& YES & 25 & 3 \\
\hline Smartphones & NO & 20 & 2 \\
& YES & 893 & 98 \\
\hline Tablet & NO & 899 & 98 \\
& YES & 14 & 2 \\
\hline Laptop & NO & 835 & 91 \\
& YES & 78 & 8 \\
\hline Personal Computer & NO & 903 & 99 \\
\hline
\end{tabular}


62 J.M.R. Asio et al.: Internet Connection and Learning Device Availability of College Students: Basis for Institutionalizing Flexible Learning in the New Normal

\begin{tabular}{lccc}
\hline & YES & 10 & 1 \\
\hline Total & & 913 & 100 \\
\hline
\end{tabular}

* Province 1 - Bataan

* Province 2 - Zambales

Table 4 shows the frequency distribution of the responses of students in the survey done in the College of Business and Accountancy. We deduct that almost 90 percent of the students will return this first semester. The majority of these returning students come from the Zambales province (90\%) and followed by the Bataan province ( $9 \%)$. In terms of the availability of internet at home, 65 percent (or 589 students) revealed they have access. However, only $38 \%$ (or 345 students) have Wifi access at home and only six percent (or 51 students) have pocket Wifi with them. On the other hand, more than half or almost 60 percent of the students rely on mobile data for internet connection and only 45 percent rely on free mobile data. It is also important to note here that 97 percent (or 888 students) have access to the internet. For gadgets, 98 percent (or 893 students) have smartphones in contrast with tablets (2\%), laptops $(8 \%)$, and personal computers $(1 \%)$.

Table 5. Survey Results from the College of Education, Arts, and Sciences

\begin{tabular}{llcc}
\hline Items & Responses & Frequency & Percentage \\
\hline Will enroll next semester & YES & 475 & 82 \\
& NO & 104 & 18 \\
\hline Province & Province 1 & 45 & 8 \\
& Province & 529 & 91 \\
& Others & 5 & 1 \\
\hline Internet access at home & NO & 202 & 35 \\
& YES & 377 & 65 \\
\hline Wifi Access at home & NO & 339 & 59 \\
& YES & 240 & 41 \\
\hline Pocket Wifi & NO & 537 & 93 \\
& YES & 42 & 7 \\
\hline Mobile data & NO & 266 & 46 \\
& YES & 313 & 54 \\
\hline Free Mobile data & NO & 301 & 52 \\
& YES & 278 & 48 \\
\hline No internet access & NO & 557 & 96 \\
& YES & 22 & 4 \\
\hline Smartphones & NO & 27 & 5 \\
& YES & 552 & 95 \\
\hline Tablet & NO & 566 & 98 \\
& YES & 13 & 2 \\
\hline Laptop & NO & 492 & 85 \\
& YES & 87 & 15 \\
\hline Personal Computer & NO & 560 & 97 \\
& YES & 19 & 3 \\
\hline Total & & 579 & 100 \\
\hline
\end{tabular}

* Province 1-Bataan

* Province 2 - Zambales

Table 5 shows the frequency distribution and percentage of responses of students in the survey done in the College of Education, Arts, and Sciences. As we observe, more than 80 percent of the students surveyed will return for the first semester of 2020-2021. The majority of these students come from the province of Zambales and Bataan. On the other hand, in terms of internet access at home, there are more students $(65 \%)$ who have access than those who do not have it. In the context of Wifi internet access at home, more than half or almost 60 percent of the students responded negatively. The same response was also observed in terms of pocket Wifi access, a majority (93\%) of the 
students do not have pocket Wifi. There are more students (54\%) who use mobile data to access the internet. However, only 48 percent of the students use free mobile data. In this regard, the majority of the students (96\%) have internet access. For the gadgets, almost all of the students (95\%) have smartphones compare to tablets (2\%), laptops (15\%), and personal computers (3\%).

Table 6. Survey Results from the Institute of Graduate Studies

\begin{tabular}{llcc}
\hline Items & Responses & Frequency & Percentage \\
\hline Will enroll next semester & YES & 53 & 100 \\
\hline Province & Province 1 & 15 & 28 \\
& Province 2 & 38 & 72 \\
\hline Internet access at home & NO & 3 & 6 \\
& YES & 50 & 94 \\
\hline Wifi Access at home & NO & 15 & 28 \\
& YES & 38 & 72 \\
\hline Pocket Wifi & NO & 48 & 91 \\
& YES & 5 & 9 \\
\hline Mobile data & NO & 20 & 38 \\
& YES & 33 & 62 \\
\hline Free Mobile data & NO & 44 & 83 \\
& YES & 9 & 17 \\
\hline No internet access & NO & 53 & 100 \\
\hline Smartphones & NO & 2 & 4 \\
& YES & 51 & 96 \\
\hline Tablet & NO & 48 & 91 \\
& YES & 5 & 9 \\
\hline Laptop & NO & 32 & 60 \\
& YES & 21 & 40 \\
\hline Personal Computer & NO & 48 & 91 \\
& YES & 5 & 9 \\
\hline Total & & 53 & 100 \\
\hline Provice & & & \\
\hline
\end{tabular}

* Province 1-Bataan

* Province 2 - Zambales

Table 6 shows the frequency distribution and percentage of responses of the students in the survey done in the Institute of Graduate Studies. It is seen that all of the students will return this First semester. And most of them come from the province of Zambales and Bataan. In terms of the availability of internet access, 94 percent of the students responded affirmatively. In line with this, there is 72 percent of them having Wifi access at home. However, only a few have pocket Wifi (only $9 \%$ ). More than half of 62 percent of the students use mobile data for internet connection and more than 80 percent do not use free mobile data. It is interesting to note that all of the students (100\%) have internet access. In terms of gadgets, the majority of the students $(96 \%)$ have smartphones compared to the tablet (9\%), laptop (40\%), and personal computer (9\%).

Table 7. Survey Results Summary

\begin{tabular}{llcc}
\hline Items & Responses & Frequency & Percentage \\
\hline Will enroll next semester & YES & 2356 & 88 \\
& NO & 318 & 12 \\
\hline Province & Province 1 & 239 & 9 \\
& Province 2 & 2405 & 90 \\
& Others & 30 & 1 \\
\hline
\end{tabular}


64 J.M.R. Asio et al.: Internet Connection and Learning Device Availability of College Students: Basis for Institutionalizing Flexible Learning in the New Normal

\begin{tabular}{llcc}
\hline \hline Internet access at home & NO & 856 & 30 \\
& YES & 1818 & 70 \\
\hline Wifi Access at home & NO & 1523 & 55 \\
& YES & 1151 & 45 \\
\hline Pocket Wifi & NO & 2500 & 87 \\
& YES & 174 & 13 \\
\hline Mobile data & NO & 1093 & 41 \\
& YES & 1581 & 59 \\
\hline Free Mobile data & NO & 1498 & 56 \\
& YES & 1176 & 44 \\
\hline No internet access & NO & 2611 & 98 \\
& YES & 63 & 2 \\
\hline Smartphones & NO & 96 & 4 \\
& YES & 2578 & 96 \\
\hline Tablet & NO & 2619 & 98 \\
& YES & 55 & 2 \\
\hline Laptop & NO & 2291 & 88 \\
& YES & 383 & 12 \\
\hline Personal Computer & NO & 2600 & 97 \\
& YES & 74 & 3 \\
\hline Total & & 2674 & 100 \\
\hline
\end{tabular}

* Province 1-Bataan

* Province 2 - Zambales

Table 7 indicates the overall results of the whole survey in the institution. As we can see, 2,674 student-respondents participated in the survey. Out of this number, 88 percent will enroll next semester and the majority of these will come from the provinces of Zambales and Bataan area.70 percent of the students have internet access in their homes. However, only 45 percent utilize Wifi access, much more interesting, only 13 percent have pocket Wifi. Almost 60 percent of students use mobile data for internet access and only 44 percent use free mobile data. Almost all of the students (98\%) revealed that they have internet access. In terms of gadgets, 96 percent of the studentrespondents have smartphones in contrast with tablets (2\%), laptops (12\%), and personal computers $(3 \%)$.

\section{Discussion}

The main objective of this survey is to assess the basic needs and available resources that the students have in line with the new normal of learning more particularly the internet connectivity and learning devices availability. This survey has identified some important findings that may help the school administration decide the best course of action and decision for its stakeholders.

In this study, the majority of the surveyed students will still return to school. However, since face to face learning is impossible due to lockdowns and special permits to travel are needed, and at the same, considering the geographical locations of the students, a large number of the students will come from the provinces. The institution will shift to other forms of teaching modalities to accommodate the learning needs of the students. With this idea, a study by Lorenzo (2017) perceived that the use of a blended learning strategy deems to be effective. However, Baloran (2020) showed in a study about the unwillingness of students towards online blended learning. 
Next, seven out of ten students have access to the internet at home. This is a good sign for an online option. This result might argue with the findings of Chung et al. (2020b) wherein internet connection is one of the great challenges of learning online among students. Although, based on the results, almost six out ten students use mobile data for internet connection other than Wifi access (45\%), free mobile data (44\%), or pocket Wifi (13\%). With this result in mind, based on the studies of Siddiquah and Salim (2017) and Bisht et al. (2020), problems in the internet signal might become a barrier among students in their learning. The same findings from the study of Wickramanayake and Muhammad Jika (2018) indicating the unreliable internet connections are one of the barriers for students. This might incur some significant amount in the financial standings of the students since work is also shut down and most of the families rely on relief goods and other resources from the government.

It is interesting to note however that most of the students have smartphones, which is an additional opportunity to maximize and exploit its learning potential. A study by Essel et al. (2018) agrees with the results. The group stipulated that students possess various types of mobile devices especially smartphones. To add, Kapasia, et al (2020) mentioned in their study that most of their studentrespondents used android mobile for attending their classes online. Another study also implied that mobile phones are well-liked by students and became one of the best tools for an educational institution to adopt (Al Tameemy, 2017). However, in the local context, these devices are still unavailable to some students. This then becomes a burden or a challenge for them especially in their learning (Cleofas \& Rocha, 2021; Yra et al., 2020). Although there are some few who possess tablets, laptops, and personal computers, they can still use this as an alternative means of learning and not rely heavily on smartphones. With these initial results, the school administration can now decide the best course of action in providing a sound academic delivery of learning.

\section{Conclusions}

Based on the result of the online survey done to the students, the researchers, therefore, conclude that internet connectivity will pose a big challenge among students for their online learning. This idea also applies to the institution, the school administration, the faculty, and the staff. However, this result will justify the recommendation for appropriate actions intended to remedy such a problem. Secondly, the study also found that a majority of students have smartphones. This possesses an opportunity for students to learn on an online basis. Mobile devices such as smartphones are a great help because of their multiple functions especially in learning nowadays. For students who do not possess such a device because of financial status, this can be remedied easily through sponsorship and other modes of donation from individuals with a willing heart.

This study also has its limitations. These can become opportunities for other researchers to exploit and make their own set of studies. First, the sample of the study, although the number might seem a good one, it still failed to consider the whole population of the institution. Second, this study was only done in just one institution of higher education, therefore it would be better if this is done with several more. Third, the locality, this study was done in a highly urbanized city, thus, this can be done also in the province or even with other cities in the region or more. Fourth, it is better to add more variables in the survey like level of readiness and satisfaction of internet connection and device performance. Fifth, it is also better to do other statistical inferences like differences and relationships in the study. Last, conduct further studies like this shortly. 


\section{Recommendations}

Based on the findings of this initial survey, the following recommendations are hereby presented: provision of pocket Wifi for students especially in far-flung areas with ample data connection. Provision of other gadgets for learning for those students who are very needy and qualified with the help of the local government units (LGUs). Provision of Wifi hotspots to certain locations where students can avail it for free in the community like a plaza, barangay halls, Barangay Police outposts, parks, etc. The provision of possible services to extend assistance and help to students in the implementation of flexible learning using online mode delivery. Improvement of I.T. infrastructure for flexible teaching and supporting the continuous learning of the students. Recalibration of program offerings and alignment of curriculum competencies based on the capability of the students and institution in the implementation of the online mode delivery of learning. Finally, the inclusion of flexible teaching and learning in the institution's strategic plan as an alternative delivery mode in the future.

\section{References}

[1] Aboagye E., Yawson, J.A., \& Appiah, K.N. (2021). COVID-19 and e-learning: the challenges of students in a tertiary institution. Social Education Research, 2(1), 1-8. https://doi.org/10.37256/ser.212021422

[2] Ahmed, S.S., Khan, E., \& Faisal, M. (2017). The potential and challenges of MOOCs in Pakistan: A perspective of students and faculty. Asian Association of Open Universities Journal, 12(1), 94-105. https://doi.org/10.1108/AAOUJ-01-2017-0011

[3] Akbar, M.A., Rachid, M.M., \& Embong, A.H. (2018). Technology-based learning system in the internet of things (IoT) education. $20187^{\text {th }}$ International Conference on Computer and Communication Engineering, Kuala Lumpur, Malaysia, 192-197. https://doi.org/10.1109/ICCE.2018.8539334

[4] Al Tameemy, F. (2017). Mobile phones for teaching and learning: Implementation and students' and teachers' attitudes. Journal of Educational Technology Systems, 45(3), 436-451. https://doi.org/10.1177/0047239516669754

[5] Apuke, O.D., \& Iyendo, T.O. (2018). University students' usage of the internet resources for research and learning: forms of access and perceptions of utility. Heliyon, 4, e01052. https://doi.org/10.1016/j.heliyon.2018.e01052

[6] Baloran, R.T. (2020). Knowledge, attitudes, anxiety, and coping strategies of students during COVID-19 pandemic. Journal of Loss and Trauma, 25(8), 635-642. https://doi.org/10.1080/15325024.2020.1769300

[7] Baltes, S., \& Raloh, P. (2021). Sampling in software engineering research: A critical review and guidelines. https://arxiv.org/pdf/2002.07764.pdf

[8] Bisht R.K., Jasola, S., \& Bisht, I.P. (2020). Acceptability and challenges of online higher education in the era of COVID-19: A study of students' perspective. Asian Education and Development Studies, (ahead of print). https://doi.org/10.1108/AEDS-05-2020-0119

[9] Casillano, N.F.B. (2019). Challenges of implementing an e-learning platform in an internet struggling province in the Philippines. Indian Journal of Science and Technology, 12(10), 1-4. https://doi.org/10.17485/ijst/2019/v12i10/137594 
[10] Chase, T.J.G., Julius, A., Chandan, J.S., Powell, E., Hall. C.S., Phillips, B.L., Burnett, R., Gill, D., \& Fernando, B. (2018). Mobile learning in medicine: An evaluation of attitudes and behaviors of medical students. BMC Medical Education, 18(152), 1-8. https://doi.org/10.1186/s12909-018-1264-5

[11] Chung E., Subramaniam, G., \& Dass, L.D. (2020a). Online learning readiness among university students in Malaysia amidst COVID-19. Asian Journal of University Education,16(2),46-58. https://doi.org/10.24191/ajue.v16i2.10924

[12] Chung, E., Noor, N.M., \& Mathew V.N. (2020b). Are you ready? An assessment of online learning readiness among university students. International Journal of Academic Research in Progressive Education \& Development, 9(1), 301-317. http://dx.doi.org/10.6007/IJARPED/v9i1/7128

[13] Cleofas, J.V., \& Rocha, I.C.N. (2021). Demographic, gadget, and internet profiles as determinants of disease and consequence related COVID-19 anxiety among Filipino college students. Education and Information Technologies, https://doi.org/10.1007/s10639-02110529-9

[14] Essel, H.B., Nunoo, F.K.N., Menson, A.T., Amankwa, J.O. (2018). Higher education students' ownership and usage of smartphones and tablets: The case of Kwame Nkrumah University of Science and Technology (KNUST). International Journal of Educational Technology, 5(1), 20 28. https://eric.ed.gov/?id=EJ1182237

[15] Estira, K.L.A. (2020). Online distance learning readiness of business administration students in one state university in the Philippines. Journal of Critical Reviews, 7(12), 826-832. http://dx.doi.org/10.31838/jcr.07.12.146

[16] Fabito, B.S., Trillanes, A.O., \& Sarmiento, J.R. (2021). Barriers and challenges of computing students in an online learning environment: Insights from one private university in the Philippines. International Journal of Computing Sciences Research, 5(1), 441-458. https://doi.org/10.2514/ijcsr.2017.001.1.51

[17] Gulatee, Y., \& Combes, B.A. (2018). Owning ICT: Student use and ownership of the technology. Walailak Journal of Science and Technology, 15(1), 81-94. https://doi.org/10.48048/wjst.2018.2868

[18] Gezgin, D.M. (2017). Exploring the influence of the patterns of mobile internet use on university students' nomophobia levels. European Journal of Education Studies, 3(6), 29-53. https://doi.org/10.5281/zenodo.572344

[19] Hossain, M.A., \& Rahman, M.H. (2017). Comparative study of internet usage among university students: A study of the University of Dhaka, Bangladesh. European Scientific Journal, 13(34), 134-150. https://doi.org/10.19044/esj.2017.v13n34p134

[20] Jin, W., \& Sabio, C.J. (2018). Potential use of mobile devices in selected public senior high schools in the city of Manila Philippines. International Journal of Learning, Teaching and Educational Research, 17(4), 102-114, https://doi.org/10.26803/ijlter17.4.7

[21] Kapasia, N., Paul, P., Roy, A., Saha, J., Zaveri, A., Mallick, R., Barman, B., Das, P., \& Chouhan, P. (2020). Impact of lockdown on learning status of undergraduate and postgraduate students during COVID-19 pandemic in West Bengal, India. Children and Youth Services Review, 116, 105195. https://doi.org/10.1016/j.childyouth.2020.105194 
[22] Lorenzo, A.R. (2017). Comparative study on the performance of Bachelor of Secondary Education (BSE) students in educational technology using blended learning strategy and traditional face-to-face instruction. Turkish Online Journal of Educational Technology, 16(3), 36-46. https://eric.ed.gov/?id=EJ1152658

[23] Muthuprasad, T., Aiswarya, S., Aditya, K.S., \& Jha, G.K. (2021). Students' perception and preference for online education in India during COVID-19 pandemic. Social Sciences \& Humanities Open, 3, 100101. https://doi.org/10.1016/j.ssaho.2020.100101

[24] Nassaji, H. (2015). Qualitative and descriptive research: Data type versus data analysis. Language Teaching Research, 19(2), 129-132. https://doi.org/10.1177/1362168815572747

[25] Serhan, D. (2020). Transitioning from face-to-face to remote learning: Students attitudes and perceptions of using zoom during COVID-19 pandemic. International Journal of Technology in Education and Science, 4(4), 335-342. https://doi.org/10.46328/ijtes.v4i4.148

[26] Siddiquah, A., \& Salim, Z. (2017). The ICT facilities, skills, usage, and the problems faced by the students of higher education. EURASIA Journal of Mathematics Science and Technology Education, 13(8), 4987-4994. https://doi.org/10.12973/eurasia.2017.00977a

[27] Sileyew, K. J. (2019). Research Design and Methodology. https://www.intechopen.com/books/cyberspace/research-design-and-methodology.

[28] Taherdoost, H. (2016). Sampling methods in research methodology; how to choose a sampling technique for research. International Journal of Academic Research in Management, 5(2), 1827. https://hal.archives-ouvertes.fr/hal-02546796

[29] Tarimo, R., \& Kavishe, G. (2017). Internet access and usage by secondary school students in Morogoro municipality, Tanzania. International Journal of Education and Development Using Information and Communication, Technology, 13(2), 56-69. https://files.eric.ed.gov/fulltext/EJ1153320.pdf

[30] Wickramanayake, L., \& Muhammad Jika, S. (2018). Social media use by undergraduate students of education in Nigeria: A survey. The Electronic Library, 36(1), 21-37. https://doi.org//10.1108/EL-02-2017-0023

[31] Yra, J.F.P., Castillo, R.H., Bautista, R.G., Camayang, J.G., \& Camayang, A.G.G. (2020). Students' online learning readiness and internet connectivity: Bases for the customization of QSU e-Aral. American Journal of Educational Research, 8(11), 878-894. https://doi.org/10.12691/education-8-11-8

\section{Biodata:}

John Mark R. Asio is currently the Research Director of the Research Development and Community Extension Services Office of Gordon College, Olongapo City, Philippines. He is also an Instructor of the Social Sciences and Philosophy Department of the College of Education, Arts, and Sciences of the same institution.

Ediric D. Gadia is the Vice President for Research Development and Community Extension Services Office of Gordon College, Olongapo City, Philippines. At the same time, he is also the Dean of the College of Education, Arts, and Sciences of the same institution 
Erlinda C. Abarintos is the Vice President for Administration and Finance Office of Gordon College, Olongapo City, Philippines. Also, she is the Dean of the College of Computer Studies of the same institution.

Darwin P. Paguio is currently the Vice President for Academic Affairs Office of Gordon College, Olongapo City, Philippines. He is also a faculty of the Mathematics and Physics Department of the College of Education, Arts, and Sciences of the same institution.

Melner Balce is currently an Instructor of the College of Computer Studies of Gordon College, Olongapo City, Philippines. 